\title{
PROFILE OF SECRETION CULTURE OF SKIN LESIONS IN THE INTENSIVE CARE UNIT
}

\author{
PERFIL DE CULTURAS DE SECREÇÕES DE LESÕES DE PELE NA UNIDADE DE \\ TERAPIA INTENSIVA
}

\section{Jaciara Aparecida de Jesus SILVA ${ }^{1}$; Lúcia Aparecida FERREIRA ${ }^{2}$; Fernanda Bonato ZUFFI ${ }^{3}$; Marina Pereira REZENDE ${ }^{4}$; Maria Cristina de MOURA-FERREIRA ${ }^{5}$; Guilherme Silva MENDONÇA ${ }^{6}$}

1. Nurse, Master's Graduate Stricto Sensu Program in Health Care, Federal University of Triangulo Mineiro; 2. Ph.D in Nursing Professor at the Federal University of Triângulo Mineiro; 3. Master Professor in Nursing - Professor at the Federal University of Triângulo Mineiro; 4. Ph.D. in Nursing - Professor at the Federal University of Triângulo Mineiro; 5. Nurse, PhD in nursing. Associate Professor. Federal University of Uberlândia, Uberlândia, MG, Brazil; 6. Nurse, Pedagogue, Master in Health Sciences, Federal University of Uberlândia, Uberlândia, MG, Brazil.

\begin{abstract}
This study aims to identify the profile of secretion culture of skin lesions in the Intensive Therapy Unit (ICU), the microorganisms present in biological samples, resistance or sensitivity to carbapenems, oxacillin and vancomycin and the site of lesion. This is a descriptive, observational and retrospective study with a quantitative approach, performed in a large public teaching hospital. 210 results of secretion cultures in ICUs were analyzed in the period from 2010 to 2014. Of these 16 were negative for any microorganism, 18 showed coagulase-negative Staphylococcus, and 176 obtained positive result for some microorganism, being sensitive to antibiotics and the operative wounds the most affected site.
\end{abstract}

KEYWORDS: Nursing. Wound. Intensive Care Unit.

\section{INTRODUCTION}

The World Alliance for Patient Safety has elaborated guidelines and programs which have sensitized health professionals and the population in favor of the health care changing, with a new view to the daily practices, identifying failures that can cause damage to the health of the subject (FERNANDO et al., 2016).

Thinking about this theme, the Intensive Care Unit (ICU) is a sector of high complexity, where the quality monitoring of the services delivered becomes more and more essential to the security of the critical client. They are in a weakened condition, susceptible to infections, complications and consequently to mortality (FERNANDES; PULZI JÚNIOR; COSTA FILHO, 2010; MARTINS et. al., 2010).

Clients who are in the ICU are predisposed to changings in the skin integrity, which are a big public health problem, burdening expenses and damaging the quality of person's life . Healing of the wound depends on numberless factors which can be local (condition of the wound and treatment used) and factors related to the clinical conditions of the clients. The client's clinical diagnosis favors the establishment of conducts and treatments for the reestablishment of his/her vital functions, improvement of the underlying pathology and consequent healing of the lesions and client's reestablishment (EBERHAEDT et al, 2015).

For that a broad antibiotic spectrum is used in the ICU by facilitating the treatment of the most diverse bacteria. Nevertheless, the erroneous antibiotic therapy is responsible for the development of the bacterial resistance, thus requiring more and more last generation antibiotics. In order to avoid the bacterial resistance, monitoring the use of antibiotics is (GRILLO et. al., 2013). Characterization of the bacterial incidence and the resistance profile is the basis for the directed and appropriate antibiotic therapy (RIGATTI, 2010.)

In this context, the objective of this work arose from the interest in identifying the profile of secretion cultures of skin lesions in on ICU, the microorganisms present in the biological samples, the resistance or sensitivity to Carbapenem, oxacillin and vancomycin and the site of the lesion, thus promoting a new look to the health team concerning the care with the wounds, improving health assistance and reducing risk of complications to the hospitalized client in the ICU.

\section{METHODS}

This is a descriptive, observational and retrospective study, with quantitative approach, carried out in a large public teaching hospital, which attends high-complexity clients, located in the 
municipality of Uberaba, Minas Gerais. Data were collected through the analysis of the results of secretion culture of skin lesions, present in the records of the microbiology department of the Clinical Pathology Service of the Hospital de Clínicas of the Federal University of Triângulo Mineiro - UFTM, of the period from 2010 to 2014, from the General and Coronary ICUs of this institution. The ICU of the hospital is subdivided in General (attends all the clinics) and Coronary (only heart diseases,) being composed by 10 beds each.

There was no protocol in the institution and in the study sector during the analyzed period, which advised when the culture collection of skin lesion secretions should be performed. The standard operating procedure (POP) of the institution discussed how the collection procedure should be performed by the medical professional or nurse. Culture was only collected when the professional who evaluated the client made the decision to collect through the signs and symptoms presented. The objective of the study was not the comparison of the ICUs, but the analysis of the microorganisms profile in the biological samples collected. Data collected were typed in an electronic spreadsheet, Excel Microsoft ${ }^{\circledR} \mathrm{XP}^{\circledR}$ Program and presented in tables containing descriptive statistics, absolute and relative frequency type (RODRIGUES, 2006).

The project was approved by Ethics Committee in Research/ National Commission on Research Ethics by means of the Platform Brasil, as well as to the approval of the teaching hospital, receiving approval Opinion $\mathrm{n}$ o 877.760. This current research is guided by the determinations of the Resolution 466/12, which regulates the research with human beings (BRASIL, 2012.)

\section{RESULTS}

210 results of culture secretions of the ICUs were analyzed from 2010 to 2014 . Of these 16 presented negative result for any microorganism, 18 presented coagulase-negative Staphylococcus, and 176 obtained positive results for some microorganism. It is noticed that positive microbiologic cultures were more frequent in the Adult ICU, 137 (77.8\%), whereas in the Coronary ICU only $39(22.2 \%)$ presented positive microbiology, as shown in Table I. When we analyze year over year, we notice that the adult ICU had higher absolute of cases in the last five years.

Table I: Number of secretion cultures of skin lesions in ICU of a teaching hospital, year over year, from 2010 to 2014. Uberaba, MG.

\begin{tabular}{lllllllllll}
\hline \multirow{2}{*}{ ICU } & $\mathbf{2 0 1 0}$ & & $\mathbf{2 0 1 1}$ & & $\mathbf{2 0 1 2}$ & $\mathbf{2 0 1 3}$ & $\mathbf{2 0 1 4}$ \\
\cline { 2 - 11 } & $\mathbf{n}$ & $\mathbf{\%}$ & $\mathbf{n}$ & $\mathbf{\%}$ & $\mathbf{n}$ & $\mathbf{\%}$ & $\mathbf{n}$ & $\mathbf{\%}$ & $\mathbf{n}$ & $\mathbf{\%}$ \\
\hline Adult ICU & 85 & $(82.5)$ & 7 & $(63.6)$ & 16 & $(61.5)$ & 11 & $(84.6)$ & 18 & $(78.3)$ \\
Coronary ICU & 18 & $(17.5)$ & 4 & $(36.4)$ & 10 & $(38.5)$ & 2 & $(15.4)$ & 5 & $(21.7)$ \\
\hline Total & 103 & $(100.0)$ & 11 & $(100.0)$ & 26 & $(100.0)$ & 13 & $(100.0)$ & 23 & $(100.0)$ \\
\hline
\end{tabular}

Concerning the prevalent microorganisms in the positive microbiological cultures, it was observed that there were more positive results for
Pseudomonas aeruginosa $34 \quad(19.3 \%)$, Acinetobacter baumanii $33(18.8 \%)$ and Klebsiella pneumoniae 31 (17.6\%) (Table II).

Table II: Number of microorganism found in secretion cultures of skin lesions in the ICU of a teaching hospital, year over year, from 2010 to 2014. Uberaba, MG.

\begin{tabular}{llllll}
\hline MICROORGANISM & $\mathbf{2 0 1 0}$ & $\mathbf{2 0 1 1}$ & $\mathbf{2 0 1 2}$ & $\mathbf{2 0 1 3}$ & $\mathbf{2 0 1 4}$ \\
\cline { 2 - 6 } & $\mathbf{n}$ & $\mathbf{n}$ & $\mathbf{n}$ & $\mathbf{n}$ & $\mathbf{n}$ \\
\hline Pseudomonas aeruginosa & 22 & 2 & 4 & 3 & 3 \\
Klebsiella pneumoniae & 17 & 1 & 8 & 4 & 1 \\
Acinetobacter baumanii & 16 & 3 & 6 & 1 & 7 \\
Enterobacter cloacae & 16 & 2 & 1 & - & 1 \\
Escherichia coli & 11 & - & - & 2 & - \\
Proteus mirabilis & 8 & 1 & 1 & 2 & 1 \\
Staphylococcus aureus & 5 & 1 & 3 & - & - \\
Enterobacter aerogenes & 4 & - & - & 1 & - \\
Enterococcus faecalis & 2 & 1 & 2 & - & 7 \\
Citrobacter freundi & 1 & - & - & - & - \\
Morganella morganii & 1 & - & - & - & - \\
Pseudomonas fluorescens & - & - & 1 & - & - \\
\hline
\end{tabular}




\begin{tabular}{llllll}
\hline Klebsiella oxytoca & - & - & - & - & 1 \\
Proteus vulgaris & - & - & - & - & 1 \\
Acinetobacter lwoffii & - & - & - & - & 1 \\
\hline Total & 103 & 11 & 26 & 13 & 23 \\
\hline
\end{tabular}

Of the 176 positive results for some microorganism, 155 were Enterobacteria (Pseudomonas, Klebsiella, Acinetobacter, Escherichia coli and Proyours), 12 were Enterococcus spp., and 9 Staphylococcus aureus. Related to the resistance of the Enterobacteria to the Carbapenem, the result of the microbiological cultures showed that from the 155 enterobacteria, $122(78.7 \%)$ presented sensitivity to Carbapenem and 31 (20.0\%) were resistant. In respect to the resistance of Enterococcus spp to Vancomycin, 7 (100.0\%) of the cases were sensitive. It was verified that of the 9 cases of Staphylococcus aureus, 3 (33.3\%) were resistant to the Oxacillin, and 6 (66.6\%) were sensitive.

As regards the injury we observed a high number of microbiological analyses without the identification of the wound site. In other words, the professional who filled out the request did not put the name of the infected site. Related to those which were identified correctly by the health professional, $24(13.6 \%)$ of the infections took place in surgical wound of the abdomen ; 18 (10.2\%) surgical wound of the chest; $18(10.2 \%)$ sacral pressure ulcer; 14 $(8.0 \%)$ surgical wound of the lower limb; $8(4.5 \%)$ burn; $6(3.4 \%)$ cervical surgical wound; $5(2.8 \%)$ occipital pressure ulcer; low limb pressure ulcer 5 $(2.8 \%) ; 3(1.7 \%)$ high limb pressure ulcer; 2 (1.1 $\%)$ feet pressure ulcer; $1(0.6 \%)$ dorsal surgical pressure ulcer; $1(0.6 \%)$ hip surgical wound; 1 (0.6 $\%)$ ulcer by dorsal dorsal region pressure; $1(0,6 \%)$ surgical head wound, according to Table III.

Table III: Number of sites where secretion cultures were collected, in the ICU of a teaching hospital, year over year, from 2010 to 2014. Uberaba, MG.

\begin{tabular}{llllll}
\hline LESION SITE & $\mathbf{2 0 1 0}$ & $\mathbf{2 0 1 1}$ & $\mathbf{2 0 1 2}$ & $\mathbf{2 0 1 3}$ & $\mathbf{2 0 1 4}$ \\
\cline { 2 - 6 } & $\mathbf{n}$ & $\mathbf{n}$ & $\mathbf{n}$ & $\mathbf{n}$ & $\mathbf{n}$ \\
\hline Pressure ulcer: no identification of the site & 9 & 1 & 4 & - & 5 \\
Dorsal region surgical wound & 1 & - & - & - & - \\
Low limb surgical wound & 7 & 2 & - & - & 5 \\
High limb surgical wound & 1 & 1 & - & - & - \\
Hip surgical wound & 1 & - & - & - & - \\
Surgical wound: no identification of the & 26 & 4 & 5 & 4 & 3 \\
site & & & & & \\
No identification by the professional who & 5 & - & 1 & - & 3 \\
filled out the culture requirement. & & & & & \\
Burn & 4 & - & 1 & 3 & - \\
Dorsal region pressur ulcer & 1 & - & - & - & - \\
Cervical surgical Wound & 4 & - & 2 & - & - \\
Occipital pressure ulcer & 4 & - & - & - & 1 \\
Sacral pressure ulcer & 14 & 1 & 2 & - & 1 \\
Low limb pressure ulcer & 3 & - & - & 2 & - \\
Ulcer by high member pressure & 3 & - & - & - & - \\
Feet pressure ulcer & 2 & - & - & - & - \\
Head surgical wound & 1 & - & - & - & - \\
Chest surgical wound & 7 & 2 & 4 & 2 & 3 \\
Abdomen surgical wound & 13 & - & 7 & 2 & 2 \\
\hline Total & 103 & 11 & 26 & 13 & 23 \\
\hline
\end{tabular}

\section{DISCUSSION}

Technological advances in ICU extended the life of numberless people, with prolonged length of stay, more invasive, diagnostic and therapeutic procedures. However, factors such as inappropriate aseptic techniques, incorrect use of antimicrobials and inappropriate care with skin integrity, besides clinical conditions of the patient, facilitated the 
emergence of antimicrobial-resistant microorganisms.

In this study it is observed that in the period from 2010 to 2014 only 176 secretion cultures were found in the registers of the Microbiology department of the Hospital Clinical Pathology Service. It has made us reflect on the small number of secretion cultures of lesions collected by the professionals of the sector, since the hospital is reference in complexity for the region, what turns the ICUs into places with extremely complex patients and exposed to numerous invasive procedures.

The greatest occurrence of positive results in adult ICU, $148(76.3 \%)$, is due to the fact that it is a place that receives patients who underwent contaminated surgeries, such as the digestive tract surgeries and traumas. It does not happen in the Coronary ICU, as it only admits patients proceeding from cardiac surgeries, angioplasties, pacemaker implantation and heart failure (OLIVEIRA; BRAZ; RIBEIRO, 2007). The highest number of culture secretions collected in 2010 (103 cases) was justified by the ICU staff and the Hospital Infection Control Commission (CCIH) as the year in which the units attended a higher number of clients with lesions of Skin, and mainly due to the profile of the professionals who worked in the ICUs in this period. They were professionals who based the treatment prescribed not only in the clinic, but in the performance of examinations such as the culture of secretions.

The $\mathrm{CCIH}$ is responsible for the epidemiological and microbiological surveillance, control of the use of antimicrobials and preparation of prevention routines, diagnosis and treatment of the infection in the health care services. The reduction of the number of cases can be related to a better performance of the $\mathrm{CCIH}$ team inside these unities, with programs of prevention and direction of the professionals that composes the assistance (GIAROLA et al, 2012).

Concerning the prevalent microorganism in the positive microbiologies, this study corroborated other studies showing that in the isolated microorganisms in the ICU, Pseudomonas aeruginosa comes first, followed by coagulagenasenegative Staphylococcus, Staphylococcus aureus, Enterobacter spp., Klebsiella spp. and
Acinetobacter baumanii (OLIVEIRA; KOVNER ; SILVA, 2010; JÚLIO, 2013).

Acinetobacter spp. and Pseudomonas aeruginosa are gram-negative bacteria with very little nutritional needs and can survive for long periods in dry and humid surfaces, becoming a risk to immunosuprressed patients in hospital environments, since they can cause infections and consequently sepsis. A study carried out in the University Hospital of Santa Maria, corroborated our study showing a high number of cases of these bacteria in the ICU (SANTOS; BREZOLIN; HORNER, 2014.)

Regarding the places where the cultures were collected, it was observed a great number of secretion collections in the surgical site. The infections of surgical site are important causes of post-operative complications, according to the Center for Disease Control and Prevention (CDC), 14 to $16 \%$ of the hospital infections are related to the ISC (OLIVEIRA; BRAZ; RIBEIRO, 2007; JÚLIO, 2013). However, the infections in ulcers by pressure also deserve attention, since patients in intensive therapy are most of the time under mechanical ventilation, exposed to humidity and with no decubitus change.

The resistance to antibiotics appears as a consequence of the mutation of bacteria, in front of the irrational use of antimicrobials, mainly in methicillin-resistant Staphylococcus aureus (MRSA) , Enterococcus sp resistant to the vancomycin and gram-negative bacteria resistant to Carbapenem (LAXMINARAAYAN et. al., 2013). It was noticed in our research that the gram-negative bacteria or enterobacteria were sensitive to carbapenes, as well as the Staphylococcus aureus to Oxacillin and the Enterococcus sp to Vancomycin.

\section{CONCLUSION}

The results of this study contributes to base other works on the profile of secretion cultures in lesions, reinforcing the importance of a program of an effective control of infections program with the involvement of all multiprofessional team. It emphasizes the importance of prevention measures to the skin lesions that are generated to the clients in the scope of the ICU, either intentionally or not, stimulating a safe environment for the client and the professional.

RESUMO: Este estudo tem como objetivo identificar o perfil de culturas de secreções de lesões de pele na UTI, os microrganismos presentes nas amostras biológicas, à resistência ou sensibilidade aos Carbapenem, Oxacilina e Vancomicina e o local da lesão. Trata-se de um estudo descritivo, observacional e retrospectivo, com abordagem 
quantitativa, realizado em um hospital público de ensino de grande porte. Foram analisados 210 resultados de culturas de secreções das UTIs no intervalo de 2010 a 2014. Dessas 16 apresentaram resultado negativo para qualquer microrganismo, 18 apresentaram Staphylococcus coagulase negativo, e 176 obtiveram resultado positivo para algum microrganismo, sendo sensíveis aos antibióticos e o local mais acometido as feridas operatórias.

PALAVRAS-CHAVE: Enfermagem. Ferida. Unidade de Terapia Intensiva.

\section{REFERENCES}

BRASIL. Ministério da Saúde. Resolução 466, de 12 de dezembro de 2012. D.O.U., Brasília, 13 jun. 2012. Disponível em: <http://conselho.saude.gov.br/resolucoes/2012/Reso466.pdf>. Acesso em: [20 set. 2014].

EBERHARDT, T. D.; DIAS, C. F. C.; FONSECA, G. G. P.; KESSLER, M.; SOARES, R. S. A.; LIMA, S. B. S.. Cicatrização de feridas: análise das tendências em teses e dissertações. Rev Enferm UFSM, Santa Maria, v. 5, n. 1, p. 387-395. 2015. https://doi.org/10.5902/2179769215259

FERNANDES, H. S.; PULZI JÚNIOR, S.A.; COSTA FILHO, R.. Qualidade em terapia intensiva. Rev Bras Clin Med., São Paulo, v. 8, p. 37-45. 2010.

FERNADO, F. S. L.; ALMEIDA, M. T. G.; OLIVEIRA, K. A.; LOPES, V. S.; MORESCHI, C. L.. Segurança do Paciente: Análise Reflexiva. Rev Enferm UFPE on line, Recife, v. 10, n. 2, p. 894-902. 2016. DOI: 10.5205/reuol.6884-59404-2-SM-1.1002sup201626

GIAROLA, L. B.; BARATIERI, T.; COSTA, A. M.; BEDENDO, J.; MARCON, S. S.; WAIDMAN, M. A. P. Infecção hospitalar na perspectiva dos profissionais de enfermagem: um estudo bibliográfico. Cogitare Enferm., Curitiba, v. 17, n. 1, p. 151-157, 2012. https://doi.org/10.5380/ce.v17i1.26390

GRILlO, V. T. R. S.; GONÇALVES, T. G.; CAMPOS JÚNIOR, J.; PANIÁGUA, N. C.; TELES, C. B. G. Incidência bacteriana e perfil de resistência a antimicrobianos em pacientes pediátricos de um hospital público de Rondônia, Brasil. Rev. Cien. Farm. Básica Apl., Araraquara, v. 34, n. 1, p. 117-123, 2013.

LAXMINARAYAN, R.; DUSE, A.; WATTAL, C.; ZAIDI, A. K. M.; WERTHEIM, H. F. L.; SUMPRADIT, N.; VLIEGHE, E.; HARA, G. L.; GOULD, I. M.; GOOSSENS, H.; GREKO, C.; SO, A. D.; BIGDELI, M.; TOMSON, G.; WOODHOUSE, W.; OMBAKA, E.; PERALTA, A. Q.; QAMAR, F. N.; MIR, F.; KARIUKI, S.; BHUTTA, Z. Q. A.; COATES, A.; BERGSTROM, R.; WRIGHT, G. D.; BROWN, E. D.; CARS, O... Antibiotic resistence-the need for global solutions. Lancet Infect Dis., New York, n. 13, p. 1057-98. 2013. https://doi.org/10.1016/S1473-3099(13)70318-9

MARTINS, L.; FERNANDES, A.; FONTES, D.; SERRANO, A.; ORNELAS, H.. Sépsis associadas aos cateteres venosos centrais. Acta Pediátr. Port., Lisboa, v. 41, n. 1, p. 5-7, 2010. Doi: 0873-9781/10/41-1/5

OLIVEIRA, A. C.; BRAZ, N. J.; RIBEIRO, M. M. Incidência da infecção do sítio cirúrgico em um hospital universitário. Cien. Cuid. Saúde, Maringá, v. 6, n. 4, p.486-493, Out/Dez. 2007.

OLIVEIRA, A. C.; KOVNER, C. T.; SILVA, R. S. Infecção hospitalar em unidade de tratamento intensivo de um hospital universitário brasileiro, Rev Latino-Am. Enferm., Ribeirão Preto, v. 18, n. 2, p. 97-104, Mar/Abr. 2010.

RIGATTI, F. Detecção da resistência à oxacilina e perfil de sensibilidade de Staphylococcus coagulase negativos isolados em um hospital escola. Dissertação. Santa Maria: Centro de Ciências da Saúde, Universidade Federal de Santa Catarina; 2010. 
SANTOS, S. O.; BREZOLIN, D.; HORNER, R. Acinetobacter spp e Pseudomonas aeruginosa resistentes aos carbapenêmicos no Hospital Universitário de Santa Maria, Rio Grande do Sul. Scientia Medica, Porto Alegre, v. 24, n. 2, p. 150-155. 2014. https://doi.org/10.15448/1980-6108.2014.2.15809 